\title{
Mesenchymal stem cells transplantation reduces diabetic nephropathy
}

\author{
Abeer Kazmi ${ }^{1}$, Arsheema Kazmi ${ }^{2}$, Wali Muhammad ${ }^{3}, *$, Muhammad Azhar ${ }^{3}$
}

${ }^{1}$ Department of Biotechnology, Faculty of Chemical and Life Sciences, Abdul Wali Khan University 23390, Mardan, KP, Pakistan

${ }^{2}$ Stem Cells Regenerative Medicine Lab, Department of Biochemistry, Abdul Wali Khan University 23200, Mardan, KP, Pakistan

${ }^{3}$ Department of Biotechnology, Quaid-i-Azam University 45320, Islamabad, Pakistan

Correspondence

Wali Muhammad, Department of Biotechnology, Quaid-i-Azam University 45320, Islamabad, Pakistan

Email:wali.biotech5511@gmail.com

History

- Received: 2019-03-08

- Accepted: 2019-03-27

- Published: 2019-03-31

DOI :

https://doi.org/10.15419/psc.v6i1.403

\section{Check for updates}

Copyright

(-) Biomedpress. This is an openaccess article distributed under the terms of the Creative Commons Attribution 4.0 International license.

\begin{abstract}
Diabetes mellitus is a metabolic disease in which the pancreas is unable to produce enough insulin due to the destruction of $\beta$-cells or the body does not utilize insulin properly. Continuous fluctuation of blood glucose levels is responsible for prolonged complications such as diabetic nephropathy (DN), diabetic retinopathy, or diabetic cardiomyopathy. Approximately, 20-30\% of all diabetic patients face DN, which causes the formation of diabetic glomerular lesions and reduced glomerular filtration rate. In the case of renal failure, kidney transplantation is the only available therapy, however, it is expensive and almost unattainable due to unavailability of donors and host immune rejection. Stem cells are an alternative and attractive source of therapy because of their proliferative nature and the ability to produce distinct specialized cells. Mesenchymal stem cells (MSCs), which are derived from bone marrow, possess an anti-inflammatory property and the ability of selfrenewal and differentiation into a variety of specialized cells. MSCs are widely used to treat different diseases including DN and they have shown encouraging outcomes. This review provides details about the regenerative efficiency of using MSCs in treating diabetic nephropathy.
\end{abstract}

Key words: Diabetes mellitus, Diabetic Nephropathy, Stem cells, Regeneration, Mesenchymal stem cells

\section{INTRODUCTION}

Diabetes mellitus is a metabolic/ autoimmune/ hormonal/ endocrine disease consisting of elevated blood glucose levels. It is considered as an outbreak with a constant increase both in ratio and frequency around the globe ${ }^{1}$. The number of patients with diabetes in 1980 was 108 million, which rised up to 415 million in 2015, and is estimated to reach 642 million by $2040^{2}$. In 2012, 1.5 million deaths were reported from all over the world due to diabetes. Globally, diabetes was the eighth foremost cause of death among both males and females and was the fifth leading cause of death in women in $2012^{3}$. There are two types of diabetes mellitus, type 1 (T1D) and type 2 (T2D). T2D is the most common form of diabetes and 90-95\% peoples are affected with T2D. It is usually developed due to the permutation of auxiliary insulin opposition which progressively damages pancreatic $\beta$-cells and leads to complete failure of endogenous insulin secretory cells. Chronic high blood glucose leads to complications including macroangiopathy and microangiopathy, retinopathy, chronic nephropathy, peripheral and central neuropathy, and cardiomyopathy ${ }^{4}$. At the starting phase of T2D, insulin opposition can be a coup but it ultimately requires exogenous insulin against functional $\beta$-cells exhaustion. 5-10\% of people are affected by T1D at a younger age and require acute exogenous insulin therapy. Regrettably, though exogenous insulin therapy may hold up disease progression, it does not eliminate the risk of the disease's chronic convolution ${ }^{5}$.

In pharmacologic therapy, different drugs are developed to control blood glucose levels, blood pressure and obstruction of the renin-angiotensin-aldosterone system (RAAS), however, these strategies only slow the progression of renal damage ${ }^{6}$.

Podocytes show a high level of constitutive autophagy, a passageway in which altered proteins, as well as organelles, are transported to lysosomes that represent a defensive system against podocyte aging and glomerular damages ${ }^{7}$. Therefore, modulating autophagy represents a useful therapeutic way to slow the succession of DN.

All these strategies can only delay the progression of renal damage but cannot stop or reverse renal damage due to diabetes. Stem cells (SCs) based therapies are expected to bring significant advantages to patients suffering a broad range of diseases and injuries. Various types of stem cells are found in the body and can be utilized for the treatment of numerous diseases (Figure 1).

Stem cells are widely used for the regeneration of cells/tissues damaged due to chronic diseases because of their unique properties: 


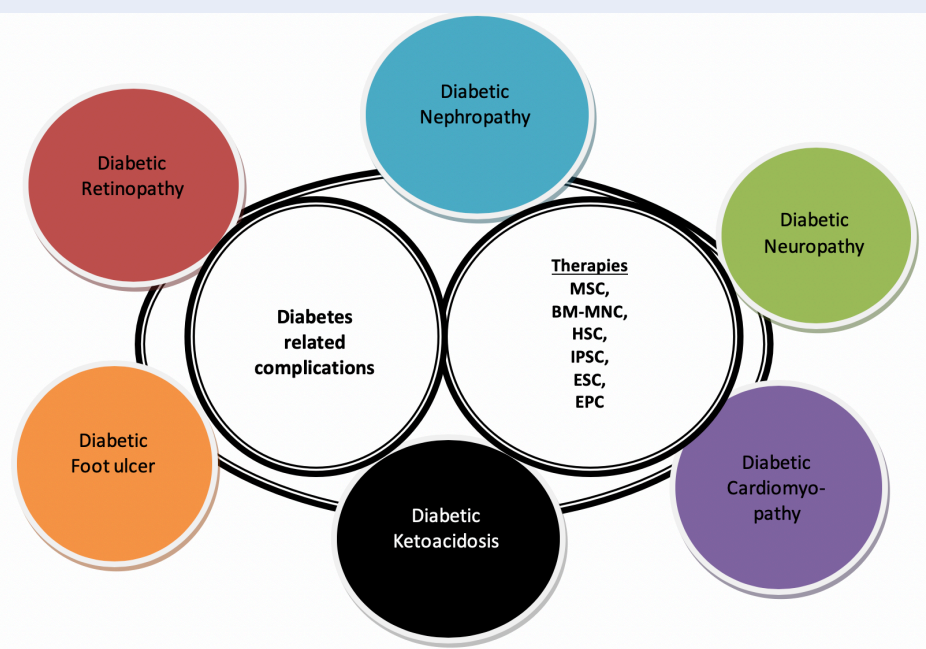

Figure 1: Therapeutic options for vascular complications in diabetes by Stem Cells Mesenchymal stem cell (MSC); Bone marrow-derived mononuclear cell (BM-MNC); Hematopoieticstem cell (HSC); Induced pluripotent stem cell (iPSC); Embryonic stem cell (ESC);Endothelial progenitor cell (EPC).

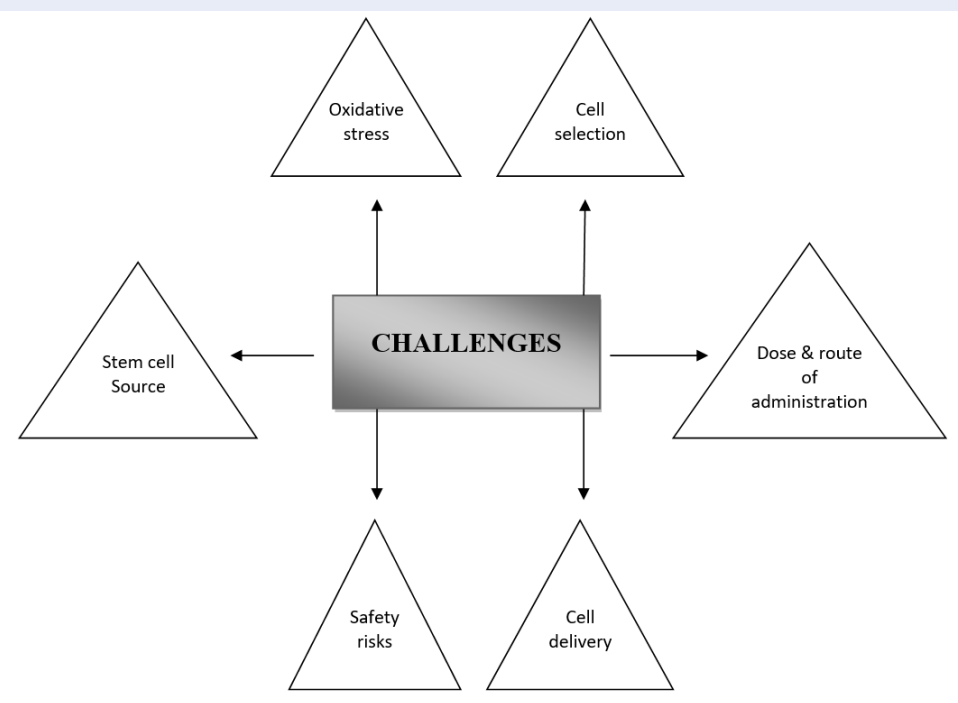

Figure 2: Challenges during stem cell therapy.

(i) self-renewal (capability to generate symmetric daughter cells),

(ii) long-term viability and

(iii) potentiality to produce distinct specialized cells ${ }^{8}$. However, the selection of stem cell types, techniques of cell isolation, culturing and injection into a patient are delicate and require expertise. Challenges faced during stem cell therapy are mentioned in Figure 2. 
Table 1: Biomarkers used for monitoring MSC in Diabetic Nephropathy

\begin{tabular}{|c|c|c|c|c|c|}
\hline Animal model used & $\begin{array}{l}\text { MSC } \\
\text { isolation }\end{array}$ & $\begin{array}{l}\text { Number of } \\
\text { cells injected }\end{array}$ & Biomarkers & Results & References \\
\hline Sprague-Dawley rats & BM-MSCs & $2 \times 10^{6}$ & $\begin{array}{l}\text { Nephrin and podocin, } \\
\text { podocyte survival factors } \\
\text { (VEGF and BMP-7) }\end{array}$ & $\begin{array}{l}\downarrow \text { blood glucose levels and albuminuria Improvement in renal mass } \\
\text { indication }\end{array}$ & 9 \\
\hline BALB/C mice & BM-MSCs & $2 \times 10^{9}$ & $\begin{array}{l}\text { nephrin, CD2AP, synap- } \\
\text { topodin, TRPC6 }\end{array}$ & $\begin{array}{l}\downarrow \text { Urine protein excretion and foot process fusion, protect } \\
\text { podocytes from PAN damage }\end{array}$ & 10 \\
\hline $\begin{array}{l}\text { C57BL/ } 6 \text { mice, } \\
\text { male Sprague-Dawley rats, } \\
\text { OLETF rats, and LETO rats }\end{array}$ & BM-MSCs & $1 \times 10^{4}$ & $\begin{array}{l}\text { Igf- } 1, \quad \text { Ifn- } \gamma, \text { Il- } 1 \beta, \text { Il- } 2 \text {, } \\
\text { Rantes, and } \alpha \text {-Sma }\end{array}$ & $\begin{array}{l}\text { Umbilical cord extract } \uparrow \text { therapeutic effect of BM-MSC and reduces } \\
\text { renal damage }\end{array}$ & 11 \\
\hline Wistar rats & BM-MSCs & $2 \times 10^{6}$ & $\begin{array}{l}\text { IL- } 1 \beta, \text { IL- } 6 \text {, TNF } \alpha \text {, and hep- } \\
\text { atocyte growth factor (HGF) }\end{array}$ & $\begin{array}{l}\text { Inhibition of MCP- } 1 \text { expression by secreting HGF, } \downarrow \text { macrophages } \\
\text { infiltration, down-regulating IL- } 1 \beta \text {, IL- } 6 \text {, TNF } \alpha \text { expression in re- } \\
\text { nal tissue }\end{array}$ & 12 \\
\hline Sprague Dawley rats & BM-MSCs & $2 \times 10^{6}$ & $\begin{array}{l}\text { Expressions of PAI-1, TGF- } \\
\text { b1 and Smad3 were detected }\end{array}$ & $\begin{array}{l}\downarrow \text { the expression of PAI- } 1 \text { protein, } \\
\downarrow \text { the accumulation of extracellular matrix and fibrosis }\end{array}$ & 13 \\
\hline Albino rats & BM-MSCs & $10^{6}$ & TGF $\beta$, TNF $\alpha$, bcl 2 and $\mathrm{Bax}$ & $\begin{array}{l}\text { Improved urinary albumin, serum urea, and creatinine concentra- } \\
\text { tion, } \uparrow \text { VEGF, and } \mathrm{Bcl} 2 \text { while } \downarrow \text { TNF- } \alpha \text {, TGF } \beta \text {, and Bax. }\end{array}$ & 14 \\
\hline $\begin{array}{l}\mathrm{C} 57 \mathrm{BL} / 6 \text { and } \mathrm{C} 57 \mathrm{BL} / 6-\mathrm{Tg} \\
\text { mice }\end{array}$ & BM-MSCs & $0.5 \times 10^{6}$ & $\begin{array}{l}\text { The expression level of } \\
\text { type I collagen, TGF-beta1, } \\
\text { laminin-beta1, fibronectin, } \\
\text { nephrin, bFGF, EGF, HGF, } \\
\text { IL-4, IL-10, and GAPDH was } \\
\text { detected }\end{array}$ & MSCs preserved renal function & 15 \\
\hline NOD/scid mice & $\begin{array}{l}\text { h-BM- } \\
\text { MSCs }\end{array}$ & $2.5 \times 10^{6}$ & $\begin{array}{l}\text { RT-PCR assay performed } \\
\text { with } 200 \text { ng of target DNA, } \\
\text { Alu-specific primers, and a } \\
\text { fluorescent probe }\end{array}$ & $\begin{array}{l}\uparrow \text { pancreatic insulin content and islet cell number } \downarrow \text { renal } \\
\text { macrophage infiltration Improvement in renal histology }\end{array}$ & 16 \\
\hline C57BL/6 mice & BM-MSCs & $0.5 \times 10^{6}$ & - & $\downarrow$ blood glucose levels $\downarrow$ albuminuria and glycosuria & 17 \\
\hline
\end{tabular}




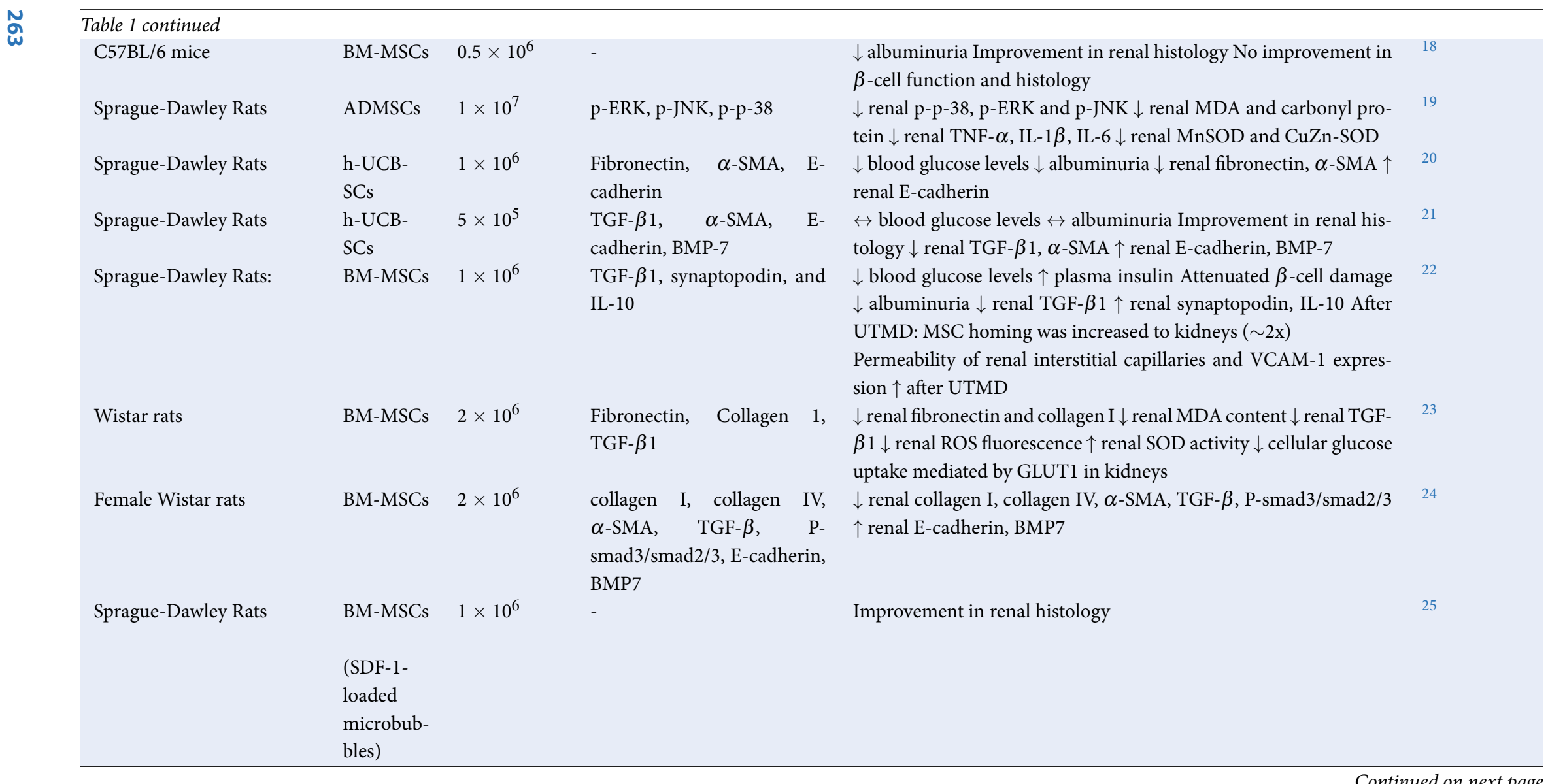




\begin{tabular}{llll}
\hline $\begin{array}{l}\text { Table } 1 \text { continued } \\
\text { Male Sprague-Dawley (SD) } \\
\text { rats }\end{array}$ & ADMSCs $1 \times 10^{5}$ & Bax -3, Bcl-2, klotho & $\begin{array}{l}\downarrow \text { the rate of cellular apoptosis, } \\
\downarrow \text { Bax and Wnt } / \beta \text {-catenin levels, } \uparrow \text { Bcl-2 and klotho levels. klotho } \\
\text { knockdown reversed the effects of ADMSCs on the expression of } \\
\text { apoptosis-related proteins and Wnt/ } \beta \text {-catenin pathway members. } \\
\text { male albino rats }\end{array}$ \\
& BM-MSCs $1 \times 10^{6}$ & - & $\begin{array}{l}\text { blood glucose level was improved, } \\
\text { renal function was retained, body weight loss was } \downarrow \text {, insulin level } \\
\text { and HBA1C percentage were ameliorated with improved oxidative } \\
\text { stress in kidney tissue }\end{array}$ \\
\hline
\end{tabular}


MESENCHYMAL STEM CELLS (MSCS)

MSCs are multipotent in nature and can be obtained from different sources. Many preclinical studies have demonstrated that mesenchymal stem cells (MSCs) enhance the regenerative wound microenvironment. In different animal models, full thickness excisional wounds $^{28}$, diabetic foot ulcers ${ }^{29}$, pressure ulcers ${ }^{30}$ and burn injuries ${ }^{31}$ can be treated by the administration of MSCs, which improves wound healing by the accelerated wound closure, reduced scarring, promoted collagen synthesis, angiogenesis, and improved tensile strength.

Advantages of MSCs for therapeutic uses include simple culturing technique, multilineage repopulation (differentiation), the potential of immunosuppressive effects, protection after inoculation of allogeneic cells and no ethical problems that transpire in case of human ESC application. Previous studies on disease models and clinical trials showed a positive therapeutic value of MSCs. MSCs can be isolated from different sources such as bone marrow, adipose tissues $^{32}$, umbilical cord blood ${ }^{33}$, peripheral blood ${ }^{34}$ and amniotic fluid ${ }^{35}$. However, bone marrow is the richest source of MSCs. Previous studies showed that MSCs can differentiate into insulin-producing $\beta$ cells $^{36}$, mesangial cells ${ }^{37}$, tubular epithelial cells ${ }^{38}$, endothelial cells, and podocytes ${ }^{39}$. Due to its effectiveness and safety, allogeneic MSCs are also used in the treatment of acute kidney injury, clinical trials and cardiomyopathy patients, who are at elevated risk of post-operative chronic kidney diseases ${ }^{40}$.

\section{MESENCHYMAL STEM CELLS FOR DIABETIC NEPHROPATHY}

Diabetic nephropathy is one of the complications of diabetes mellitus, which leads to end-stage renal damage in extreme case ${ }^{41}$. Around $25-40 \%$ of diabetic patients will develop DN. Until now, therapies for DN remain limited and none of them can completely reduce the risk of developing DN. Nowadays, the full renin-angiotensin system blockage, strict blood glycemic and lipid control are the main treatments of $\mathrm{DN}$. On the other hand, DN gives rise to kidney failure, which requires kidney transplantation and inflicts huge medical and socio-economic encumbers $^{42}$. There is an instant need to develop a regenerative strategy for which MSCs play a vital role ${ }^{43}$. In animal models, streptozotocin (STZ) was induced to cause T1D in mice. Toxicity of streptozotocin was reduced by the administration of MSCs, which regenerated damaged nephrons due to DN and resulted in enhanced renal and pancreatic function ${ }^{44}$. Injection of human-derived MSCs in NOD/SCID mice reduced both mesangial thickening and macrophage infiltration $^{45}$.

Transplantation of MSCs enhanced proteinuria and podocyte injury in T1D rat model. The effect of MSCs on the regeneration of glomerular podocyte injury was investigated on Sprague-Dawley rats, the diabetic model was developed by the induction of STZ injection (65 mg/kg, intraperitoneally). Nephrin and podocin expression levels, two major proteins involved in the formation of incision diaphragm were investigated. MSC injection extensively reduced diabetic-induced glomerular nephrin and podocin expression. Most importantly, MSC injection increased BMP-7 but not VEGF levels (BMP-7 and VEGF are podocyte survival factors). The intraarterial administration of MSCs averted the progression of albuminuria and the impairment of podocytes, although blood sugar levels were not improved. MSC protective role may be intervened by the rise of BMP-7 secretion ${ }^{9}$.

MSC administration enhanced kidney weight, renal to body weight index, urinary albumin to creatinine ratio and clearance in rats, moreover, the loss of podocytes was reduced. MSC therapy also eliminated foot processes and its widening, glomerular basal membrane thickening, and glomerular nephrin and podocin loss. Similar results were observed when MSCs and ciclosporin A were injected intracardially in combination in rats ${ }^{46}$.

In another study, MSCs were used to treat impaired podocytes by the induction of PAN ( $0.5 \mathrm{mg} / \mathrm{g}$ weight) in $\mathrm{BALB} / \mathrm{C}$ mice via tail vein. The expressions of nephrin, CD2AP, synaptopodin and TRPC6 were investigated. After administration of BMSCs, the expression of nephrin, CD2AP, and synaptopodin was up-regulated, while TRPC6 was down-regulated. Administration of BMSCs reduced excretion of protein through urine and protected podocytes from deleterious effects of PAN ${ }^{10}$.

In a novel study, BM-MSCs along with human umbilical cord extract were used to enhance the proliferative capability of BM-MSCs against DN. The therapeutic potential of BM-MSCs was reduced in diabetic patients due to oxidative stress, while umbilical cord extract contained different growth factors, extracellular matrices, and exosomes, which enhanced the proliferation of BM-MSCs. The relative mRNA expression of Igf- 1 was downregulated, whereas If $n-\gamma$, Il$1 \beta, I l-2$, and Rantes were up-regulated in treated rats as compared to controls. The expressions of $\alpha$-Sma, which represented the stress fiber of MSCs, was also increased $^{11}$. 
The mechanism of the renoprotective role of MSCs was not clear until a study showed a relationship between MSCs and macrophages in diabetic nephropathy. The hepatocyte growth factor (HGF) and proinflammatory cytokines expression at molecular and protein levels were studied, and animal groups administrated with MSCs showed elevated expression of HGF. Meanwhile, the expressions of IL- $1 \beta$, IL-6, and $\mathrm{TNF} \alpha$ were extensively decreased. The results explained that in diabetic rats, MSC transplantation minimized DN through HGF secretion, which inhibited MCP-1 expression and reduced macrophages infiltration in renal tissue ${ }^{12}$.

In rats, the effect of BMSCs on PAI-1 and renal fibrosis with DN was studied. Expressional levels of PAI-1, TGF- $\beta 1$ and Smad 3 genes in a kidney of rat model were determined; in control group, the expression of PAI-1, TGF-b1 and Smad3 were down-regulated as compared to the DN group. The pathway may be associated with the inhibition of TGF-b1/Smad 3 as the expression of PAI-1 protein was decreased and the accretion of ECM reduced, thus, balancing the fibrinolytic system ${ }^{13}$.

\section{CONCLUSION}

It is reported that MSC isolation methods in different laboratories or from different donors are highly diverse. Cell passage and in vitro culture conditions affect the phenotypes of bone marrow-derived MSCs. Moreover, aging and aging-related disorders drastically impair the survival and proliferative and differentiation potential of BM-MSCs, which limits its therapeutic efficiency. In diabetes, reactive oxygen species are generated, which affects the regenerative properties and survival of stem cells in patients with diabetes. The microenvironment under diabetic conditions is harsh for stem cells to survive or migrate to the targeted site and exert their reparative functions. Limited synthesis of proteoglycans and glycosaminoglycans in the surrounding environment causes minimal proliferation and viability of MSCs in vivo. The production of advanced glycosylated end products also inhibits proliferation of MSCs by activating apoptotic mechanism and reactive oxygen species production. In diabetic patients, oxidative stress may also influence the paracrine effects of MSCs under hypoxic conditions. In addition, the migratory capacity of MSCs is also impaired. High osteoprotegerin in diabetic patients neutralizes the pro-migratory activity of TNF-related apoptosis-inducing ligands, which promotes the migration of bone marrow stem cells.
The current review is based to summarize the work done for treatment of diabetic nephropathy and the gaps available for research. Accordingly, the use of antioxidants, growth factors or hormones along with MSCs in optimal combinations and concentrations will be appreciated.

\section{FUTURE PROSPECTS}

Stem cell-based therapy holds promising treatments for DN. Although kidney-specific stem cells have been identified in recent years, the involvement of these stem cells in the regeneration of the kidney is still in doubt. It is required to continue seeking a better and ideal cell source or to develop optimized manipulation methods for existing cells to treat DN. No matter whether the target is podocytes, PTECs or other cell types in DN, the ideal cell candidate for cell replacement should have the following properties: easy access with no safety or ethical issues, high survival rate during diabetic stress and differentiation potential into the desired cell types both in vitro and in vivo. Recently, iPSCs generated from somatic cells as well as functional kidney cells and tissues differentiation from pluripotent stem cells (ESCs and iPSCs) provide a wonderful platform to explore disease mechanisms and potential cell sources. However, the safety issue remains unsolved. Criteria for the validation of induced renal progenitor cells need to be established. The tumorigenic property of iPSCs based on viral transduction technology must be eliminated before clinical transplantation. The development of iPSCs without viral vectors might be helpful in the generation of iPSCs from an autologous source.

Bone marrow-derived MSCs remain an attractive autologous cell source mainly due to the ease of harvesting and their low immunogenicity. USCs or urinederived iPSCs from DN patients might also serve as a suitable source of cells for investigating the pathogenetic mechanisms, screening new treatments and offering possibilities for future personalized regenerative therapies.

\section{COMPETING INTERESTS}

The authors declare no conflict of interest.

\section{AUTHORS' CONTRIBUTIONS}

All the authors contribute equally to this paper.

\section{ACKNOWLEDGMENTS}

The authors are thankful to Muhammad W for his continuous support. 


\section{REFERENCES}

1. Bluestone JA, Herold K, Eisenbarth G. Genetics, pathogenesis and clinical interventions in type 1 diabetes. Nature. 2010;464(7293):1293-300. 20432533. Available from: 10 . 1038/nature08933.

2. Federation ID. Diabetes Atlas; 2015. .

3. WHO Mortality Database; 2016. Available from: http://apps. who.int/healthinfo/statistics/mortality/causeofdeath_query/.

4. Ashcroft FM, Rorsman P. Diabetes mellitus and the $\beta$ cell: the last ten years. Cell. 2012;148(6):1160-71. 22424227. Available from: 10.1016/j.cell.2012.02.010.

5. Jensen RA, Agardh E, Lernmark A, Gudbjörnsdottir S, Smith $\mathrm{NL}$, Siscovick DS, et al. HLA genes, islet autoantibodies and residual C-peptide at the clinical onset of type 1 diabetes mellitus and the risk of retinopathy 15 years later. PLoS One. 2011;6(3):e17569. 21412422. Available from: 10.1371/journal. pone.0017569.

6. Hostetter TH. Prevention of end-stage renal disease due to type 2 diabetes. N Engl J Med. 2001;345(12):910-2. 11565525. Available from: 10.1056/NEJM200109203451209.

7. Hartleben B, Gödel M, Meyer-Schwesinger C, Liu S, Ulrich T, Köbler $\mathrm{S}$, et al. Autophagy influences glomerular disease susceptibility and maintains podocyte homeostasis in aging mice. J Clin Invest. 2010;120(4):1084-96. 20200449. Available from: 10.1172/JCI39492.

8. Godfrey KJ, Mathew B, Bulman JC, Shah O, Clement S, Gallicano GI. Stem cell-based treatments for Type 1 diabetes mellitus: bone marrow, embryonic, hepatic, pancreatic and induced pluripotent stem cells. Diabet Med. 2012;29(1):14-23. 21883442. Available from: 10.1111/j.1464-5491.2011.03433.x.

9. Wang S, Li Y, Zhao J, Zhang J, Huang Y. Mesenchymal stem cells ameliorate podocyte injury and proteinuria in a type $1 \mathrm{di}-$ abetic nephropathy rat model. Biol Blood Marrow Transplant. 2013;19(4):538-46. 23295166. Available from: 10.1016/j.bbmt. 2013.01.001.

10. Chen Y, Chen J, Wan J, Gao N, Cui J, You D, et al. Bone marrow-derived mesenchymal stem cells ameliorate nephrosis through repair of impaired podocytes. Clin Invest Med. 2017;40(1):13-24. 28218578. Available from: 10.25011/cim. v40i1.28050.

11. Nagaishi $K$, Mizue $Y$, Chikenji T, Otani M, Nakano M, Saijo $Y$, et al. Umbilical cord extracts improve diabetic abnormalities in bone marrow-derived mesenchymal stem cells and increase their therapeutic effects on diabetic nephropathy. Sci Rep. 2017;7(1):8484. 28814814. Available from: 10.1038/ s41598-017-08921-y.

12. Lv SS, Liu G, Wang JP, Wang WW, Cheng J, Sun AL, et al. Mesenchymal stem cells transplantation ameliorates glomerular injury in streptozotocin-induced diabetic nephropathy in rats via inhibiting macrophage infiltration. Int Immunopharmacol. 2013;17(2):275-82. 23791972. Available from: 10.1016/j. intimp.2013.05.031.

13. Lang $\mathrm{H}$, Dai $\mathrm{C}$, Lang $\mathrm{H}$. Effects of Bone Marrow Mesenchymal Stem Cells on Plasminogen Activator Inhibitor- 1 and Renal Fibrosis in Rats with Diabetic Nephropathy. Arch Med Res. 2016;47(2):71-7. 27018336. Available from: 10.1016/j.arcmed. 2016.03.002.

14. Aziz MTA, Wassef MA, Ahmed HH, Rashed L, Mahfouz S, Aly MI, et al. The role of bone marrow derived-mesenchymal stem cells in attenuation of kidney function in rats with diabetic nephropathy. Diabetol Metab Syndr. 2014;6(1):34. 24606996. Available from: 10.1186/1758-5996-6-34.

15. Ezquer F, Giraud-Billoud M, Carpio D, Cabezas F, Conget $P$, Ezquer M. Proregenerative Microenvironment Triggered by Donor Mesenchymal Stem Cells Preserves Renal Function and Structure in Mice with Severe Diabetes Mellitus. vol. Volume 2015. BioMed Research International; 2015.

16. Lee $R H$, Seo $M J$, Reger $R L$, Spees $J L$, Pulin $A A$, Olson $S D$, et al. Multipotent stromal cells from human marrow home to and promote repair of pancreatic islets and renal glomeruli in diabetic NOD/scid mice. Proc Natl Acad Sci USA.
2006;103(46):17438-43. 17088535. Available from: 10.1073/ pnas.0608249103.

17. Ezquer FE, Ezquer ME, Parrau DB, Carpio D, Yañez AJ, Conget PA. Systemic administration of multipotent mesenchymal stromal cells reverts hyperglycemia and prevents nephropathy in type 1 diabetic mice. Biol Blood Marrow Transplant. 2008;14(6):631-40. 18489988. Available from: 10.1016/j.bbmt. 2008.01.006.

18. Ezquer F, Ezquer M, Simon V, Pardo F, Yañez A, Carpio D, et al. Endovenous administration of bone-marrow-derived multipotent mesenchymal stromal cells prevents renal failure in diabetic mice. Biol Blood Marrow Transplant. 2009;15(11):135465. 19822294. Available from: 10.1016/j.bbmt.2009.07.022.

19. Fang Y, Tian X, Bai S, Fan J, Hou W, Tong H, et al. Autologous transplantation of adipose-derived mesenchymal stem cells ameliorates streptozotocin-induced diabetic nephropathy in rats by inhibiting oxidative stress, pro-inflammatory cytokines and the p38 MAPK signaling pathway. Int J Mol Med. 2012;30(1):85-92. 22552764.

20. Park JH, Park J, Hwang SH, Han H, Ha H. Delayed treatment with human umbilical cord blood-derived stem cells attenuates diabetic renal injury. Transplant Proc. 2012;44(4):1123-6. 22564642. Available from: 10.1016/j.transproceed.2012.03.044.

21. Park JH, Hwang I, Hwang $\mathrm{SH}, \mathrm{Han} \mathrm{H}, \mathrm{Ha} \mathrm{H}$. Human umbilical cord blood-derived mesenchymal stem cells prevent diabetic renal injury through paracrine action. Diabetes Res Clin Pract. 2012;98(3):465-73. 23026513. Available from: 10.1016/j.diabres.2012.09.034.

22. Zhang Y, Ye C, Wang G, Gao Y, Tan K, Zhuo Z, et al. Kidney-targeted transplantation of mesenchymal stem cells by ultrasound-targeted microbubble destruction promotes kidney repair in diabetic nephropathy rats. BioMed Res Int 2013;2013:526367. 23762850. Available from: 10.1155/2013/ 526367.

23. Lv S, Cheng J, Sun A, Li J, Wang W, Guan G, et al. Mesenchymal stem cells transplantation ameliorates glomerular injury in streptozotocin-induced diabetic nephropathy in rats via inhibiting oxidative stress. Diabetes Res Clin Pract. 2014;104(1):143-54. 24513119. Available from: 10.1016/j. diabres.2014.01.011.

24. Lv S, Liu G, Sun A, Wang J, Cheng J, Wang W, et al. Mesenchymal stem cells ameliorate diabetic glomerular fibrosis in vivo and in vitro by inhibiting TGF- $\beta$ signalling via secretion of bone morphogenetic protein 7. Diab Vasc Dis Res. 2014;11(4):251-61. 24845071. Available from: 10.1177/ 1479164114531300.

25. Wu S, Li L, Wang G, Shen W, Xu Y, Liu Z, et al. Ultrasoundtargeted stromal cell-derived factor-1-loaded microbubble destruction promotes mesenchymal stem cell homing to kidneys in diabetic nephropathy rats. Int J Nanomedicine. 2014;9(1):5639-51. 25516709.

26. Ni W, Fang Y, Xie L, Liu X, Shan W, Zeng R, et al. AdiposeDerived Mesenchymal Stem Cells Transplantation Alleviates Renal Injury in Streptozotocin-Induced Diabetic Nephropathy. J Histochem Cytochem. 2015;63(11):842-53. 26215800. Available from: 10.1369/0022155415599039.

27. Ahmed MM, Hussein I. Ameliorative Effect of Mesenchymal Stromal Cells on Diabetic Nephropathy in Male Rats. Zagazig Veterinary Journal. 2017;45(2):125-33. Available from: 10. 21608/zvjz.2017.7885.

28. Arno Al, Amini-Nik S, Blit PH, Al-Shehab M, Belo C, Herer E, et al. Human Wharton's jelly mesenchymal stem cells promote skin wound healing through paracrine signaling. Stem Cell Res Ther. 2014;5(1):28. 24564987. Available from: 10.1186/scrt417.

29. Kato J, Kamiya H, Himeno T, Shibata T, Kondo M, Okawa T, et al. Mesenchymal stem cells ameliorate impaired wound healing through enhancing keratinocyte functions in diabetic foot ulcerations on the plantar skin of rats. J Diabetes Complications. 2014;28(5):588-95. 25027388. Available from: 10.1016/j.jdiacomp.2014.05.003.

30. de la Garza-Rodea AS, Knaän-Shanzer S, van Bekkum DW. 
Pressure ulcers: description of a new model and use of mesenchymal stem cells for repair. Dermatology. 2011;223(3):266-84. 22116308. Available from: 10.1159/ 000334628.

31. Liu L, Yu Y, Hou Y, Chai J, Duan H, Chu W, et al. Human umbilical cord mesenchymal stem cells transplantation promotes cutaneous wound healing of severe burned rats. PLoS One. 2014;9(2):e88348. 24586314. Available from: 10.1371/journal. pone. 0088348 .

32. Zuk PA, Zhu M, Ashjian P, Ugarte DAD, Huang J, Mizuno $H$, et al. Human adipose tissue is a source of multipotent stem cells. Mol Biol Cell. 2002;13(12):4279-95. 12475952. Available from: 10.1091/mbc.e02-02-0105.

33. Romanov YA, Svintsitskaya VA, Smirnov VN. Searching for alternative sources of postnatal human mesenchymal stem cells: candidate MSC-like cells from umbilical cord. Stem Cells. 2003;21(1):105-10. 12529557. Available from: 10.1634/ stemcells.21-1-105.

34. Chong PP, Selvaratnam L, Abbas AA, Kamarul T. Human peripheral blood derived mesenchymal stem cells demonstrate similar characteristics and chondrogenic differentiation potential to bone marrow derived mesenchymal stem cells. J Orthop Res. 2012;30(4):634-42. 21922534. Available from: 10.1002/jor.21556.

35. 't Anker PSI, Scherjon SA, van der Keur CK, Noort WA, Claas $\mathrm{FH}$, Willemze $\mathrm{R}$, et al. Amniotic fluid as a novel source of mesenchymal stem cells for therapeutic transplantation. Blood. 2003;102(4):1548-9. 12900350. Available from: 10.1182/ blood-2003-04-1291.

36. Karnieli O, Izhar-Prato Y, Bulvik S, Efrat S. Generation of insulin-producing cells from human bone marrow mesenchymal stem cells by genetic manipulation. Stem Cells. 2007;25(11):2837-44. 17615265. Available from: 10.1634/ stemcells.2007-0164.

37. Imasawa T, Utsunomiya $Y$, Kawamura T, Zhong $Y$, Nagasawa R, Okabe $M$, et al. The potential of bone marrow-derived cells to differentiate to glomerular mesangial cells. J Am Soc Nephrol. 2001;12(7):1401-9. 11423569.

38. Poulsom R, Forbes SJ, Hodivala-Dilke K, Ryan E, Wyles S,
Navaratnarasah $\mathrm{S}$, et al. Bone marrow contributes to renal parenchymal turnover and regeneration. J Pathol. 2001;195(2):229-35. 11592103. Available from: 10.1002/path. 976.

39. Prockop DJ. Repair of tissues by adult stem/progenitor cells (MSCs): controversies, myths, and changing paradigms. Mol Ther. 2009;17(6):939-46. 19337235. Available from: 10.1038/ mt.2009.62.

40. Tögel FE, Westenfelder C. Kidney protection and regeneration following acute injury: progress through stem cell therapy. Am J Kidney Dis. 2012;60(6):1012-22. 23036928. Available from: 10.1053/j.ajkd.2012.08.034.

41. Molitch ME, DeFronzo RA, Franz MJ, Keane WF, Mogensen CE, Parving $\mathrm{HH}$, et al. Nephropathy in diabetes. Diabetes Care. 2004:27:79-83. 14693934. Available from: 10.2337/diacare.27. 2007.S79.

42. Tang SC, Lai KN. The pathogenic role of the renal proximal tubular cell in diabetic nephropathy. Nephrol Dial Transplant. 2012;27(8):3049-56. 22734110. Available from: 10.1093/ndt/ gfs 260 .

43. Pittenger MF, Mackay AM, Beck SC, Jaiswal RK, Douglas R, Mosca JD, et al. Multilineage potential of adult human mesenchymal stem cells. Science. 1999;284(5411):143-7. 10102814. Available from: 10.1126/science.284.5411.143.

44. Ezquer ME, Ezquer FE, Arango-Rodríguez ML, Conget PA. MSC transplantation: a promising therapeutic strategy to manage the onset and progression of diabetic nephropathy. Biol Res. 2012;45(3):289-96. 23283438. Available from: 10.4067/S071697602012000300010 .

45. Lee RH, Seo MJ, Reger RL, Spees JL, Pulin AA, Olson SD et al. Multipotent stromal cells from human marrow home to and promote repair of pancreatic islets and renal glomeruli in diabetic NOD/scid mice. Proc Natl Acad Sci USA 2006;103(46):17438-43. 17088535. Available from: 10.1073/ pnas.0608249103.

46. Zhou $\mathrm{H}$, Tian HM, Long $\mathrm{Y}$, Zhang $\mathrm{XX}$, Zhong $\mathrm{L}$, Deng $\mathrm{L}$, et al. Mesenchymal stem cells transplantation mildly ameliorates experimental diabetic nephropathy in rats. Chin Med J (Engl). 2009;122(21):2573-9. 19951572. 